\title{
Deleted in Azoospermia Protein 1
}

National Cancer Institute

\section{Source}

National Cancer Institute. Deleted in Azoospermia Protein 1. NCI Thesaurus. Code C124849.

Deleted in azoospermia protein $1(744 \mathrm{aa}, \sim 83 \mathrm{kDa})$ is encoded by the human DAZ1 gene. This protein is involved in spermatogenesis. 